\title{
Al-Jurjānī's Rhetorical System of Speech in Arabic and Stylistic Studies in Modern Linguistics
}

\author{
Salahuddin Mohd. Shamsuddin \\ Prof. Dr., Faculty of Arabic Language, \\ University Islam Sultan Sharif Ali. Brunei Darussalam \\ Siti sara Binti Hj. Ahmad \\ Assoc. Prof. Dr. Dean., Faculty of Arabic Language, \\ University Islam Sultan Sharif Ali. Brunei Darussalam
}

\begin{abstract}
Rhetorical System of Speech in Arabic is an arrangement of the meanings of single words based according to the order of Arabic Grammar, as their locations amongst the meanings of single words, not among the words themselves, although it is also necessary that the arrangement has to be among themselves, as they are utensils of the meanings, they inevitably follow them in their positions. If it is necessary for the meaning to be found first in the soul, it is also necessary for the word to be first in pronunciation to indicate that meaning. Single meanings of the words without the grammatical arrangements have no value, as well as the single word has no value, but inside the sentence. The differentiation between a word and another word as being the sounds merely cannot be without the description, as one of them is familiar and the other is savage alien on the tongue of speaker or that one is lighter on the tongue has a beautiful impact in the ears and the other is difficult to pronounce hated by the hearing. The description of the eloquence while saying "these words are eloquent" does not mean to describe that the words are eloquent, as they are words merely, because they are not only the single words. The description of eloquence is given to the appropriateness of meaning of the word according to the meaning of the word followed and the other words like that, as they are not attached to the pronunciation explicitly.
\end{abstract}

Keywords: Rhetorical Sciences in Arabic: Science of Semantics; Statement; Unique Style; alJurjānī’s Rhetorical Approach in Arabic; Linguistics; Curriculums of Modern Stylistic Studies.

\section{INTRODUCTION: (ARABIC LANGUAGE)}

Everything has to be in its suitable place, therefore, it is better to quote here a page has written by Mușțafā Șādiq al-Rafi'ī in his book: "History of Arab Etiquette and Standard Arabic", he says: "It is decided by the wise men, that if the language is rich because of its vocabularies, and its wide conditions of disposing, it is a clear evidence for the civilization of its people, and their capacity under the shadow of their society. There is nothing to mention for the Arabs except that they had a literal civilization characterized by the nature; as they had noting in the science of metals and places of industries. There was not in their hands the tools of nations and social facilities except a few belongings do not reach in its entirety to be a brief explanation of the term (the Arabs) in the dictionary of nations. The wisdom that made the Old civic arts in the hands of Chinese, and civic sciences in the minds of Greeks, summarized the civilization of languages for the tongues of Arabs.

If we think about the meaning of civilization, including its benefit for us, we have seen it in every society in two forms: the first form is the image of the individual in his core, and the second is the apparent image of the group. The urbanization will not be true only if it is based 
on the mental qualities found in per capita including the preparation for the virtues that are the material of the changing in the mental growth and creation of a new origination entails the emergence of history in total. There is no doubt that the apparent atmosphere of the society is the mirror of inner changes in the individuals. The society in its meaning is such as the combined effects of the minds and history of psychological changes.

If we consider that in the Arabs we have not seen it in them as the fact nor as the appearance, but only in the language, because it is not enough for Arab to be on an innate morality protected by the borders of desert, and maintained by the walls of natural liberty, therefore, it can be said that there is a developing soul in Arabs for the literature; because this literature did not occur the mental changes in them that can be appeared in the image of their society, but in the last reign of their ignorant age when they entered in Islam, but if we consider their language we see the fact of urbanization represented, with all of its necessary conditions; it was the sea of life, which focused all the elements spewed out this mental power in their own perfect language.

The wisdom gave their nature this linguistic system, and made them to do the best for the process of its perfection, so that they do not face any obstacle to change their faces from the civil system. They went on that language beyond the social grades step by step, and at the end they became united in the unity of a nation in the world, then they changed completely, as a new young force faced by the old countries with a shock that demolished the history and then wrote a new history. If there was not this language the Arabs could not be organized because their generations to the next generations had spent before in the urbanization of their language, but they did not prove any talent in themselves, they did not consider the nature of social system, which is a way to save the life, to complete the system of life, as it is concerned by the social civilization. The language leaded them to the social ethics by the poetry, to the political guidance by the rhetorical speech, and to the religious guidance by the Holy Qur'an.

The faces of urbanization that suit the natures of the civilian purposes are those grammatical signs that specify the meanings and purposes by the most convenient signal, that are the features of mental Highness specifically. [1]

In terms of the eloquence and rhetoric in Arabic we pointed to the issue of word and meaning at Arab rhetoricians, especially theory of the systems of speech in Arabic by 'Abdul Qāhir alJurjānī, considering that his theory in the system of speech has a great impact on the modern linguistic sciences, especially on the modern stylistic study in the West, because the words in themselves have not a great value in the consideration of beautiful or ugly method; therefore, the comparison between the word and another word as being the spoken sounds, not merely to be one of them is the familiar liked in the use, and the other is brutal strange on the tongues and pens or one of them is light on the tongue has a beautiful impact in the ears, and the other is the heavy in its pronunciation hated by the hearing,[2] but the description of eloquence is given to the appropriateness of the meaning of the word to the meaning of the word that follows. [3]

If the word deserves to be described as being an eloquent should be found in the word only not in the meaning, but it is not true; because the advantage of the word as being eloquent cannot be achieved but only when it is used in the speech according to the system of speech, and if it is so, it must be known necessarily that the advantage is because of the meaning, not the word.[4] It is also said by 'Abdul Qāhir al-Jurjānī in this regard: "However, we can say that the advantage of the word, as being eloquent must not be for such words separated from the words that are 
used in the syntax, but the advantage of the word as being eloquent must be connected to the other words, and its meaning must be linked with the sense of the words followed."

We should be alert here that the expression of 'Abdul Qāhir in some places raises the illusion that the system of speech is located among the words, not among their meanings, as he said: "You have to know that "the system of speech" is only to put your words in the situation required by "Arabic grammar", according to its grammatical rules and assets."[5] So he said: "The system of speech" has no sense without the accordance of grammatical meaning of the words used as the speech."(6) He said: "The system of speech cannot be imagined without the accordance of grammatical meanings envisaged from the connection among the words used in speech... [7]

We can support what is said by Shafic al-Sayyid: "The rhetorical search remained as a descriptive analytical act in the first place, embraces the phrase, trying to extract its significance from the reality of its formation, leaving to address the emerging methods in the same way. However, this approach squeezed at the hands of a group of the rhetorical scientists came later. They believed that the values of sentences in the expression do not differ from the values of health and right, they both are characterized by the stability, as they both are gained by the observance of the grammatical rules established. Thus the rhetorical search mostly approached to the science of Arabic grammar and became as such assets, or to be similar to the grammatical rules as being a standard science includes a set of rules distributed into the three sciences: Science of the meanings, the statement and science of the new styles (al-Badī'). Rhetorical purposes remained as they are handed down from generations of scholars repeating the same examples and models, without an awareness that the subject of rhetorical study, as being the methods of expression change and evolve, depending on the different human experiences with their extent and depth, and the increasing contact to other cultures, taking from them and making them benefited for it. This is a fundamental point of difference between the traditional rhetoric, and modern stylistic study. While the old rhetorical Sciences remained confined to the set of rules by the scientists of the sixth century $\mathrm{H}$. and succeeded by the interpreter and commentators, separating it from the stream of literary expression renewed. On the contrary, modern stylistic study stripped to a descriptive analytical tendency responding to the variables, not freezes at any rule or certain rules spinning around them. [8]

\section{RHETORICAL SCIENCES IN ARABIC \\ 1. Definition of the three rhetorical sciences in Arabic \\ A. Eloquence}

It is used in Arabic language for many meanings, including the explanation and clarification, as God said in Qur'an: "and my brother Aaron more eloquent than me", and as it is said: "The boy is eloquent in his language", if his words are clear. As Arabs used to say: "The dawn is eloquent" if it is bright and lighted, as well. It is said also: "The language of foreigner became eloquent" if his language became clear, as he was not eloquent before. As well "the tongue became eloquent" is used if it is able to explain what the man has inside his self and shown clearly without any error. [9]

The eloquence in the Rhetorical terminology is a use of fully perfect words in the statement. This is limited to the word only, not to the meaning, so it is characterized by the verbal word and speech. 


\section{B. Fluency}

It is used in Arabic language: (to reach the goals), so it is said that "the man reached his goal" if he reached the end in his achievement -, as well as, "the caravan reached the city", if arrived at the city. As well as, "the thing reached its end", if it is completed. [10]

Rhetoric in the terminology is to perform the clear meaning by the correct eloquent word: has an effect in the self with the appropriateness of each word used in its suitable place in which it is said, and people who are addressed.[11] Rhetoric means to put the meaning in the heart. Therefore, it is limited to the meaning, not the word. It evidences that the eloquence includes the words and rhetoric deals with the meaning, as the parrot is called the eloquent not rhetorical bird in Arabic.

The eloquent words are apparent manifestly, because they are familiar to be used in their suitable places by the thoughtful writers and poets. They are well placed according to the awareness of hearing, and which is understood by the hearing is the word, not the meaning.

According to the opinion of 'Abdul Qāhir al-Jurjānī and a group of writers who came after him, the words: eloquence, rhetoric, the explanation and dexterity are synonymous words not characterize by the vocabularies, but the speech is described by them after the investigation of the meanings, as they are used among the speeches according to their purposes that they are drafted for them. The eloquence of speech matches as the requirement of its place in the speech with the eloquence of its word in its singular and predicate form.

Abu Hilāl al-'Askari said in his book (Two arts: the poetry and prose) that the eloquence and rhetoric both words have one meaning. Al-Rāzi said that "the most rhetoricians do not differentiate between the eloquence and rhetoric. Al-Jawhari said that "the eloquence means rhetoric. Now, we would like to define the three rhetorical sciences and their themes in Arabic:

\section{Science of Semantics ('Ilm Al-Ma'ānī)}

There are some principles and rules to define the conditions of Speech in Arabic by them to be identical in accordance with the speech which is driven for that purpose.

The theme: the Arabic word, which indicates the intended secondary meanings by the speaker for the purposes of speech to be identical in accordance with the conformity. [12]

2. Science of Statement ('Ilm Al-Bayān)

There are some rules and principles to know the use of one intended meaning by different ways to the clarity of significance.

The theme: The scientists looked for the topics - of this science - used by the writers, and found three: (the simile, metaphor and metonymy). It is possible to say that it is a science searches about the simile, metaphor and metonymy. [13]

Science of the statement in the terminology of scholars of rhetorical applications is called on the three arts of the rhetorical sciences all together, and also it is used for the name of a part of these three sciences. [14]

3. Science of Unique Style ('Ilm Al-Badī')

Al-Badí': It is called in Arabic: The invention without an earlier example.

Al-Badi' Idiomatically: is a science defines the faces and features that increase the beauty of the speech, and clad it the splendor and elegance, after being it identical in accordance with the conformity. The faces of the beauty are shown either in the word, either in the meaning. The later scientists have added many kinds of features for the beauty of the statement, but the speech according to this science (Al-Badī') means (the good style) should not be called eloquent nor fluent, because (Al-Badī) or (the good style) is an external and additional subject according to the eloquence and rhetoric, it is 
intended only to make the speech more beautiful. (Al-Badī') or (the good style) is not a separate and independent science in Arabic, so it is under the science of semantics and statement. [15]

\section{MODERN LINGUISTICS AND AL-JURJĀNĪ'S RHETORICAL APPROACH IN ARABIC}

Linguistic study is a new type of the language study depends on the methods and updated means, which is not limited to this or that language and not the others. So this study should be added to the linguistic sciences in Arabic. In this study several books has appeared in Arabic, such as: (Arabic language -its meaning and its structure-), written by Tammām Hạsān, and (linguistic thinking in the Arab civilization), by 'Abdul Salām al-Musaddī, and (the principles of linguistics), by 'Ahmad Muhammad Qaddūr, who believes that the proposed renewal of the lingual study cannot be true unless it is preceded by a deep detection of the achievements of Arab scholars in each of the areas of this study and a conscious understanding of curriculum of the imported lingual study and its purposes. [16]

Linguistic studies have seen in the West an expanding and mature since the nineteenth century. This development has caused a scientific renaissance that has its effects extended until now. These studies that were an attempt to study the scientific linguistic phenomena became known as being Linguistic studies (Linguistique). This contact with all of its impact and influence paved a way to the emergence of some new scientific branches that were the primary part of the linguistics such as the psychological, social and geographical linguistics and the others. (Philology) has been emerged in eighteenth century, but it did not exceed the boundaries of the preparatory work required for the study of language. However, Ferdinand Dossosar (Died: 1913) made the boundaries of linguistics clearly, in terms of competence, which has become includes all language sectors alike, such as the sounds, morphology, grammar, lexicon and semantics, in terms of the approaches that have matured and become fruitful such as historical, comparative and descriptive approach. When the landmarks of this new science began to appear in the modern linguistic study in Arabic Arab scholars were divided between those who downplayed this science and those who magnified it. Those who downplayed it, they did not understand its extent to evaluate it truly, which was evaluated by the West. Those who magnified it, they made it the bedrock in each study. Therefore, the achievements of the old Arab Studies in the language and their curriculums became smaller in their eyes. [17]

It is right that "the linguistics should be a factor of updating, not a factor of demolition, and that should be useful for our study as being the addition and enrichment, not for the deformation and cancellations. It is expected to make it benefited, for example, by updating the curriculums of language study, clarifying this study, which suffered from the details that are beyond the field of language, and constructing some new linguistic sciences on the guidance given by modern eyes as the science of sounds, semantics and lexicography, which was not known in the study as a systematic setting or cognitive framework (Epistemological framework), with the frequent efforts and data capacity. It can also be used in the philology of Arabic language benefiting by a lot of results of comparative linguistic studies and philological studies to know the place of Arabic language among its other sisters throughout the history, and it can be benefited by the results of Etymological study to see Arab sources as a correct knowledge, and so many." [18] Especially, the semantics, because the Arabs have had a head start in the science of sounds and the creation of dictionaries. It is known that the semantics is one of the sectors of modern lingual study, and area of this science is to study the linguistic meaning on the both levels: The vocabulary and structures, though the perception of semantics was limited to the study of vocabularies and their related issues only. The truth is that the growth of the modern semantics and methodological approaches branched -as 'Abdul Salām al-Musaddī says- made it 
a pole of rotation in every linguistic search, which is inseparable from the theory of cognition and philosophy of meaning. [19] Therefore, the science of semantics was wider than any other science studying the vocabulary or dictionary or term. [20]

However, this statement does not mean in any way to cancel any form of linguistic knowledge among the Arabs such as Arabic grammar, Morphology, Philology, Semantics and Lexicon, under the pretext of renewal or keep up with the times. It should also be noted that any drawing on modern curricula must not lead to ignore the characteristics of classical Arabic and its historical, cultural and national circumstances. [21]

\section{ARAB RHETORICAL APPROACH AND CURRICULUMS OF MODERN STYLISTIC STUDIES}

There are multiple views in the style as being one of the different types of linguistic phenomena and stylistic features for a writer and poet that are mentioned in many of the researches and studies that have addressed this linguistic phenomenon, hence, a range of different approaches used by the scholars in the analysis of linguistic styles in the West emerged.

These curriculums spin mostly about the link between the "literary work and its owner", as what is said by French writer (Buffon): "Style is the man himself", had its resonance among the writers and intellectuals, as well as German philosopher (Schopenhauer 1788-1860) says explaining almost what was said by (Buffon): "The style is the features of mind and its external apparent divisions." As well as (André Gide 1869-1951) expressed the same idea, and explained in an interesting image saying: "Every new writer needs to be expressed by a new template can be valid for ratification", as well as a great man said about himself: "It is not easy to track the curved path of my mind, as its curvature does not appear, but only in my style, which will escape the attention of many people." It means that he wanted to express the same idea.

When (Marcel Proust 1871-1922) wanted to expresses the style to the writer saw that it is similar to the color to the painter. In this similarity he did not defer to what was said by (André Gide) in terms of the command in the style is not only a tactic, but "a way to the goal in the vision". [22]

Most of the scholars were agreed that there is a close relationship between the writer's style and his personality in the broadest sense of the word. Modern linguistics has devised a number of approaches to examine this relationship deeply. These approaches are as the following:

1. Approach of philological circle

2. Approach of the qualitative classification of the style

3. Significance of the keywords

4. Sources of the metaphorical images

5. Statistical methodology

Any approach of these approaches mentioned for the stylistic analysis alone is not enough to study the style as a complete critical study, but each of them has a fraction of the truth, as all of them in the opinion of some critics are only experimental attempts, and has its self-limits, but it does not prevent to make them benefited together or take advantage of at least some of them in the study of literary text.

\section{ARABIC RHETORIC BETWEEN TRADITION AND RENOVATION}

There is no doubt that there is an urgent need to develop the curriculums of rhetorical science as the curriculums of linguistic sciences in Arabic, because the human languages have to be 
evolved and renewed by the renewal of intellectual sources, as by the changing in the social concepts, the languages change to express those concepts renewed. 'Abdul 'Azīz al-Dusuqi wanted to balance among some aesthetic terms such as: "Technical radiation", "linguistic profile" and "structure of the poem based on the style of painting", as the pillars of the approach of "artistic vision", and among the three Rhetorical Science in Arabic: "The meanings", "the statement" and "the style" in an attempt to consolidate these terms, to make them more clarified and linked to the scientific heritage of Arabs, to confirm the link between tradition and renovation, because there is a large similarity between these three terms, and three sciences of the old Arabic rhetoric. No doubt that there is an agreement in the figure and number between them, but the so-called pillars of (artistic vision) are three terms, but the three pillars of Arabic rhetoric are three rhetorical sciences. [23]

It is true that Arab rhetoric has flourished in an era in which the logic, philosophy, theological and scholastic doctrines flourished, and these sciences were useful in their time, but we do not agree that these rhetorical sciences reaped the literary experience and stopped at the edge of formal things and did not play the role of linguistic beauty or literary criticism. Also we do not agree that it ignored the beauty of the meaning revealed and splendor of the art in the literary experience. [24]

If anyone says: The rhetorical sciences in Arabic in the most part, remained linked with the recipient of the speech, as these sciences do not care about the text itself, as well as do not bother the author of the text, we can say: It seems that the viewer had not studied the issue of the word and its meaning or the form and content or the thought and its technical template that became matured by 'Abdul Qāhir al-Jurjānī.[25] Therefore, we are summarizing here what is said by 'Abdul Qāhir in the system of speech in Arabic.

\section{AL-JURJĀNĪ'S APPROACH IN THE SYSTEM OF SPEECH AND GRAMMAR}

First, when we study the advantages of this approach, find that it has the advantage of resolving this issue as follows:

A. 'Abdul Qāhir believes that the word has a code to its meaning, which is converged with the opinions of old and modern critics, and School of symbolism in the language, thus the word is a symbol of thought or experience or emotion or meaning, and its value is in the symbol of its meaning, not in the rhetoric alone.

B. Stylistic relationships among the words in the opinion of 'Abdul Qāhir is a rhetorical place, which is called by him "the system of speech", as well as the other critics expressed it by the form or image. So the image is developed through a set of relations among the words in a literary text, where the rhetorical or aesthetical image can be seen.

C. 'Abdul Qāhir does not overlook the importance of the secondary meanings that are necessary or the followers of the compositions or the impact of the symbols of a voice, and psychological overtones that give the style its rhetorical connotations, and gives it an aesthetic value.

Second, we find that 'Abdul Qāhir has drafted his theory in the "system of speech" by all these values binding by them between the word and meaning, and the stylistic semantics and their secondary significances, making this system alone an appearance of the rhetoric and a base of the aesthetic value in the literary text, displaying them for the literary application, clarifying them in his book: (Signs of the miracle) in the clearest image and statement. He did not move like other Arab critics to the idea of the unity in the literary work, counting it as a necessary part of the literary work, but in order to the single literary image, which consists of a literary work as the whole. 
Creating a modern rhetoric is not easy. The biggest evidence of the difficulty is the different views about the nature of the literary word. It is a fact that the words have a group of some symbols of the voices. See the book, which is written by Stephen Ulmann entitled: (Words and their use) translated by Kamāl Muhammad Bishr entitled: "The role of the word in the language". There is another book written by Richard Trench entitled: (Study of Words) issued in London in 1910.

No doubt that the "modern stylistic study tended a descriptive analytical tendency responds to the changes in the styles and does not freeze at a certain rule or rules spinning around them."

'Abdul Qāhir in "the system of speech" seems to be influenced by Aristotle in his saying: The limits of the poetry are the possible and the example, in term of a means to influence the humans and shook their consciousness. We can say that the opinion of Aristotle did not remain as an orphan forever the years, but some similar views appeared and embodied in a particular theory known as the theory of (Pure poetry). It was a theory made by a number of European poets in the nineteenth century, which means that the poetry itself must be independent with its own effervescence that should not be derived from any musical art. [26] As Paul Valéry also said: "The poetry is not made of the ideas, but it is made of the words". [27]

It means that the poetry has a "synthetic language", while the prose has the "analytical language". The poetic experience -as being a unit- does not consist in the soul, as the regulator logical thinking consists, and it also does not follow the route of this thinking, until it comes out in a verbal image. [28]

It means that the logic of Aristotle is still living in Arab sciences as the fundamental structure for them. It is well known that "the Arabs were interested in the Aristotelian logic since Ibn alMuqaffa', they began to translate it first, and then began to explain it, summarizing it in many compilations and invoked to this logic or inspired in the development of their sciences". (29)

\section{CONCLUSION}

We say that we cannot study the foreign languages without the study of their grammatical rules, because the grammar of the language is the key to know its Accuracies and stick its forelock.

It is said that the rules of Arabic grammar are harder than the grammar of other foreign languages generally. It is not true absolutely. Yes... It is difficult because of the capacity of classical Arabic and its comprehensive grammar including the syntactic, morphological and rhetorical rules.

Actually, the difficulty is not related to the old terminology, but to the formulation of those rules in the proper context. The difficulty is not lacking if we change the terminology created by the old linguists or to add some new additions to it such as tables, maps, and long explanations more than required, but difficulty -in our opinion- is hidden in the changing nature of nomadic inherent to the nature of ancient Greek and Latin language or contemporary English. We must not put the nature of the classical Arabic under the natures of other languages, whether they are ancient or modern. Originally the languages are local and regional. If we want to study Arabic, we should go back to the simple nomadic environment, free of the old Aristotelian logic and his measurement and the free modern romantic style of English. 
The advantage of this approach is to revive the old rules of Arabic grammar and put these rules into the new order of the new formulation, so that the student can be overcome by those difficulties faced during the study of Arabic grammar since a long time.

\section{References}

Al-Rāfa'ī. Mușțafā Sādiq. (1940). History of Etiquette Arabs. Beirut: Arab Book House. Part I, pp. 213-218

Al-Jurjānī. 'Abdul Qāhir: Signs of Miracles, p. 44, and see also "Secrets of Rhetoric, corrected by Sheikh Rashīd Riḍa. p. 3

Ibid., p. 46

Ibid. pp. 400-401

Ibid. p. 81

Ibid. p. 370

Ibid. p. 454

Al-Sayyid. Shafí . (1986). Stylistic Trend in Literary Criticism. Cairo: House of the Arab thought. p. 67

Hāshimi. Aḥmad. (1994). Jewels of rhetoric. Beirut: Dār Al-Fikr. P. 7

Ibid. p. 28

'Ali al-Jārim and Mușțafa Amīn. (1993). Clear rhetoric. Cairo: Dār al-Ma'ārif. p. 8

Hāshimī. Aḥmad. (1994). Jewels of rhetoric. Beirut: Dār al-Fikr. Pp. 39-40

Al-'Ammari. 'Ali Muhammad Ḥasan. (1965). Secrets of the statement. Cairo: Arab National Printing House. Nuzha Street. p. 21

Hāshimī. Aḥmad. (1994). Jewels of rhetoric. Beirut: Dōr Al-Fikr. p. 5

Ibid. Pp. 308-309

Ibn Khaldūn: Introduction. p. 500

Al-Jurjānī. 'Abdul Qāhir. Secrets of Rhetoric. P. 69

Mandūr. Muhammad. (No date). Systematic Criticism of Arabs, p. 54

To Ṭāhā Ḥusain, p. 87

Literary Criticism at Greece, p. 246

Magazine "The culture". (1979). Special Issue on Yusuf Sibā'ī. Cairo" Egyptian Ministry of Culture. February. p. 62 al-Sayyid. Shafic . (1986). Stylistic Trend in Literary Criticism. Cairo: House of the Arab thought. p. 164

al-Dusuqī . 'Abdul 'Azīz. (1979). (Article): "Arab artistic vision and rhetoric". Magazine: The culture. February. pp. 60-61

Ibid., P. 62

Muhammad 'Abdul Mun'im Khifājī (No date): Preface: Investigation of Signs of Miracle, Printed by Cairo Library. p. 21

Muhammad Mandūr (No date). Literature and criticism, Renaissance of Egypt, Cairo pp.: 25-26

Paul Valery. An abstract thought. Essays on the language and literature, ied., J. L. Hevesi, London, Allen Wiagate. p. 85

'Izz al-Dīn Ismā'īl. (1968). Literature and its arts, House of Arab Thought. Cairo: pp. 132-134

Daif . Shawqī. (1972). Literary Search. Cairo: Seventh edition. House of the knowledge. P. 79 